\title{
RADICAL THACIPR
}

A SOCIALIST, FEMINIST, AND ANTI-RACIST JOURNAL ON THE THEORY AND PRACTICE OF TEACHING

\section{Contributors' Notes}

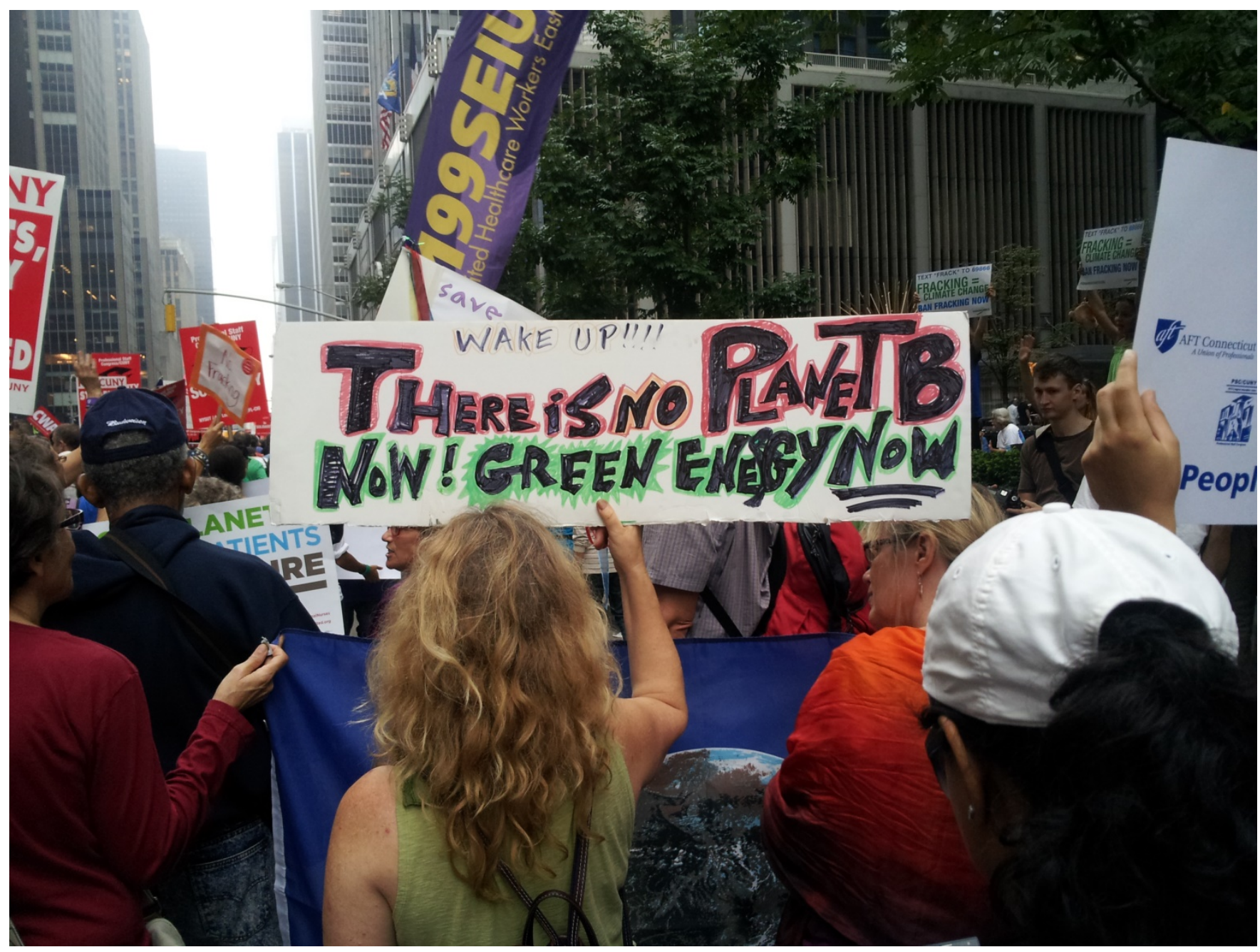

PHOTO: LEONARD VOGT 
Sara Appel is Dietrich School Postdoctoral Fellow, Department of English, University of Pittsburgh.

Bill Bigelow is the curriculum editor of Rethinking Schools and co-directs the Zinn Education Project. He is co-editor of A People's Curriculum for the Earth: Teaching Climate Change and the Environmental Crisis.

James Davis teaches English and American Studies at Brooklyn College, City University of New York.

Nicole Fabricant is an assistant professor of anthropology at Towson University in Maryland. She teaches courses on Indigeneity, Environmental (In)justice, Climate Change and Resource Politics. Her research and recent publications have centered on the Landless Peasant Movement (MST-Bolivia), a 50,000-member social movement comprised of displaced peasants, informal workers, and intellectuals fighting for land redistribution and the revitalization of small-scale farming. Her book Mobilizing Bolivia's Displaced: Indigenous Politics and the Struggle over Land (University of North Carolina Press, 2012) explores the creative ways in which displaced peoples use and mobilize cultural forms to push for political and economic reforms.

Breanne Fahs is an associate professor of women and gender studies at Arizona State University, where she specializes in studying women's sexuality, critical embodiment studies, radical feminism, and political activism. She has published widely in feminist, social science, and humanities journals and has authored four books: Performing Sex (SUNY Press, 2011), The Moral Panics of Sexuality (Palgrave, 2013), Valerie Solanas (Feminist Press, 2014), and Out for Blood (SUNY Press, forthcoming). She is the director of the Feminist Research on Gender and Sexuality Group at Arizona State University, and she also works as a private practice clinical psychologist specializing in sexuality, couples work, and trauma recovery.

Alex Kelly is a filmmaker and activist from Central Australia and is Impact Producer and Distribution Strategist on This Changes Everything.

Paul Lauter is Smith Professor Emeritus at Trinity College. During the 1960s he was director of the nation's first community school project and wrote regularly for publications like The New York Review of Books on educational issues and on the anti-war movement. He was one of the founders of Radical Teacher and intends to remain on the editorial board as it helps drown capitalism in its sauna.

Katie McKenna is the Engagement Lead for This Changes Everything.

Jason Myers has an MA from Rutgers University and an MAT from Fairleigh Dickinson University. He is currently a lecturer at William Paterson University.
Bob Rosen teaches English at William Patterson University in New Jersey.

Doreen Stabinsky is currently the Zennström visiting professor in climate change leadership at Uppsala University in Sweden. She teaches global environment politics half-time at College of the Atlantic. She also works as an independent consultant on climate and agriculture policy and politics, advising a number of developing country governments and international non-governmental organizations in the climate negotiations.

Eleanor Stein has been a life-long activist for human rights, civil rights, and peace. A founder of the upstate New York group Women Against War, for the last ten years her focus has been climate change. She teaches the Law of Climate Change: Domestic \& Transnational at Albany Law School and the State University of New York at Albany, and she is currently enrolled in the LLM program on Climate Change Law and Policy at the University of Strathclyde, Scotland. She is a member of the Board of Directors of Eco-Viva, an organization in solidarity with environmental and climate change organizations in rural El Salvador. Her recent publications include Regional Initiatives to Reduce Greenhouse Gas Emissions, in Michael Gerrard, Ed., Global Climate Change and U.S. Law, and No War for Oil, No Oil for War! with her husband, Jeff Jones, in Monthly Review Magazine's MRZine (2007).

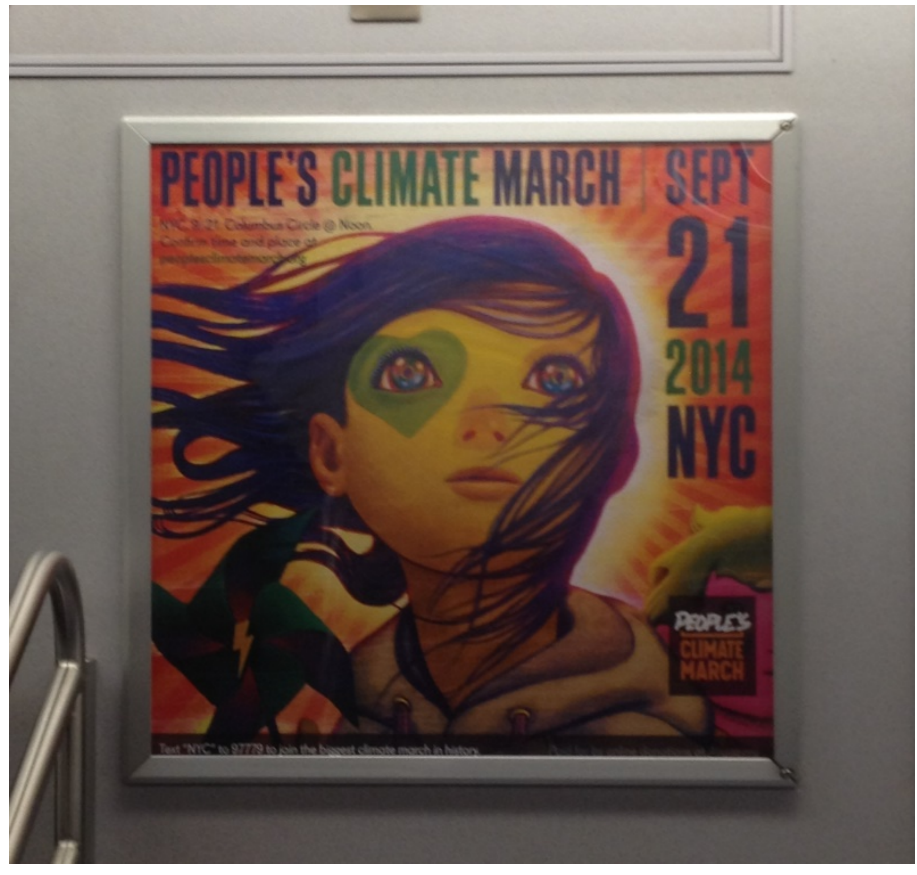

SUBWAY AD IN NYC FOR PEOPLE'S CLIMATE MARCH OF SEPTEMBER 21, 2014. PHOTO: LEONARD VOGT

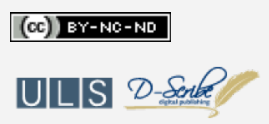

